Article

\title{
Evaluation of Daylight and Cooling Performance of Shading Devices in Residential Buildings in South Korea
}

\author{
Taesub Lim ${ }^{1}$, Woong Seog Yim ${ }^{2, *}$ and Daeung Danny Kim ${ }^{3, *(D)}$ \\ 1 Department of Architectural Engineering, Seoil University, Seoul 02192, Korea; francis9@seoil.ac.kr \\ 2 Department of Industrial Management, Seoil University, Seoul 02192, Korea \\ 3 Architectural Engineering Department, King Fahd University of Petroleum and Minerals (KFUPM), \\ Dhahran 31261, Saudi Arabia \\ * Correspondence: wsyim8452@hanmail.net (W.S.Y.); dkim@kfupm.edu.sa (D.D.K.)
}

Received: 17 August 2020; Accepted: 10 September 2020; Published: 11 September 2020

\begin{abstract}
Accounting for more than half of buildings in South Korea, the energy consumed by residential buildings has become a main concern and the cooing demand has rapidly increased. To reduce energy consumption, several passive and active design strategies have generally been applied. However, there has been an increasing demand for high window-to-wall ratios in residential buildings, it is imperative to block sunlight into a building effectively. Focusing on the reduction of cooling energy consumption in a residential building, the present study assessed the daylight and energy performance of shading devices. Among various types of shading devices, the Venetian blind, horizontal louver, light shelf, and egg-crate were selected. The illuminance levels in three different areas in a building were measured. In addition, the annual cooling energy consumption by these shading devices was investigated. As a result, both daylight and energy performance varied with different design options of these shading devices. Because of the slight performance difference among shading devices, the artificial loads of two best shading devices were compared. In sum, the egg-crate shading was the most proper shading device to block sunlight as well as reduce the cooling energy consumption effectively.
\end{abstract}

Keywords: daylight; cooling energy; shading device; residential building

\section{Introduction}

Accounting for more than half of buildings in South Korea (hereafter Korea), residential buildings have consumed a significant amount of energy and it has rapidly increased [1]. Specifically, more than half of the total building energy consumption was used by residential buildings, which was about $60 \%[2,3]$. Focusing on energy consumption by the residential sector, many studies have been conducted to improve energy efficiency and develop energy conservation measures [4-7]. Considering the effort to reduce greenhouse gas emissions, it is necessary to find ways of reducing energy consumption by residential buildings.

Generally, most of the energy in the residential building has been used for heating and cooling to maintain thermal comfort. Thus, it is necessary to reduce the heating and cooling demand in residential buildings in that the total energy consumption in buildings can be reduced. To reduce the energy for heating and cooling, building envelope-enhancement is initially considered. In general, advanced materials have been used to improve thermal resistance in building envelopes such as phase change materials, vacuum insulation panels, various types of double pane glazing, etc. [8-12]. In addition, the use of shading devices and airtightness improvement can be also effective strategies to reduce heating or cooling in buildings $[13,14]$. 
Among components of building envelopes, window systems are the main contributor to the heat loss and their energy performance generally depends on thermal properties of glazing and frames [15]. Even though the use of advanced glazing can improve the thermal performance of window systems, there are still issues about the poor thermal performance of window systems compared to other components of building envelopes [16,17]. As mentioned above, another way of reducing heating and cooling demand is the use of internal and external shading devices that can control sunlight through window systems [13]. According to the study of Cho et al. [18], external shading devices for high-rise residential buildings reduced cooling energy demand effectively by minimizing solar heat gain during the summer. Similar studies about the energy-saving potential by using external shadings were performed [19-22]. By absorbing or reflecting the sun's radiation, shading devices play a significant role to maintain thermal comfort in buildings.

Since daylighting highly influences not only the energy performance of buildings but also occupant satisfaction, productivity, and health, it is one of the most important factors that need to be considered from the architectural design stage. In addition, daylighting should be well-controlled and appropriately used to avoid a further increase in heat gains including internal heat gains such as from artificial lighting and home appliances. Regarding the recent design trend of residential buildings, the demand for high window-to-wall ratios in residential buildings in Korea is rapidly increasing. Moreover, the cooling demand has been consistently increasing $[18,23,24]$. While most studies have focused on the energy performance of in buildings, the present study assesses the daylighting and cooling energy performance of both internal and external shading devices. In addition, the relationship between the daylighting of shading devices with cooling energy demand was also investigated.

\section{The Control of Building Energy Consumption by Shading Devices}

As essential factors influencing thermal conditions in a building via thermal gains/losses, solar radiation has been controlled with shading devices [25]. Since the solar shadings were initially introduced, the interest of this area has been growing rapidly. Researchers are focusing on diverse methods that can maximize the performance of shading devices. Marrero and Oliviera [26] showed that the installation of louver shading devices in buildings can lead to more comfortable indoor thermal conditions for the residents as well as significant savings in building energy consumption. A similar result was also obtained by Lim et al. [27]. Their result showed that window glazing coupled with shading devices enhanced tropical daylighting quantity as well as visual comfort. Solar shading devices can also provide an energy saving of $8 \%$ and $20 \%$ during the winter and summer, respectively [28].

Many types of shading devices have been developed by designers and building scientists over the years. They vary in several aspects such as shape, size, and overall performance. Several shading types were investigated by Nedhal and Fadzil [29]. Among various types, the egg-crate shading had the most significant impact on the indoor air temperature decrease in high-rise residential buildings. In addition, locations, size, and color of the internal blinds can significantly influence building energy consumption and the proper design of internal blinds can save energy about $14 \%$ of total building cooling consumption during the summer season [30]. According to the study of Uribe [31], the optimum design of shading devices can influence annual energy consumption in buildings and the design variables of the shading devices should consider the time of day and seasonal differences. Focusing on the design of shading devices, window glass types, seasonal and daily temperature change, and the operation of mechanical systems for heating and cooling should be also considered [32]. Previous studies have revealed that the use of shading devices play an important role in reducing electric lighting, while it provides a required amount of light for visual tasks.

According to the study of Datta [33], externally fixed horizontal louvers with different slat lengths and tilts on buildings have a different impact on thermal conditions in buildings. Therefore, shading strategies were developed to control daylight quantities. One of the strategies brought by Tzempelikos and Athienitis [34] was the control of building cooling and lighting demand by exterior roller shades. As a result, the shading devices reduced the energy demand for cooling and lighting by limiting $20 \%$ of 
solar transmittance. Horizontally installed shading devices in buildings in tropical regions controlled solar heat gains as well as reduced HVAC (Heating, Ventilation, and Air Conditioning) loads [35]. In the case of the internal blinds, the automated Venetian blind was used to limit direct sunlight while admitting diffused sunlight for visual comfort [36]. Similarly, absorptive blinds in an office building can also reduce the indoor air temperature by $1^{\circ} \mathrm{C}$ during the summer [37].

\section{Methodology}

\subsection{Building Description}

To evaluate the daylighting and energy performance of a residential building with shading devices, a typical apartment building in Seoul in Korea was chosen, in which the latitude and longitude are $37.5665^{\circ} \mathrm{N}$ and $126.9780^{\circ} \mathrm{E}$, respectively. The annual mean air temperature in Seoul is $12.5^{\circ} \mathrm{C}$, and the highest and lowest mean air temperatures are $-2{ }^{\circ} \mathrm{C}$ and $26^{\circ} \mathrm{C}$, respectively [38]. In addition, the mean annual insolation is $4125 \mathrm{MJ} / \mathrm{m}^{2}$ [39]. The total area of the unit space was $145 \mathrm{~m}^{2}$ with a ceiling height of $2.3 \mathrm{~m}$ and located on the eighth floor of an apartment building with 17 floors. All bedrooms and the living room were headed to the south (Figure 1). Due to a high WWR of $90 \%$ of the southern wall, a large quantity of solar radiation was expected. Thermal properties and other conditions for the energy simulation were presented in Table 1. In addition, the energy model was created by SketchUp.

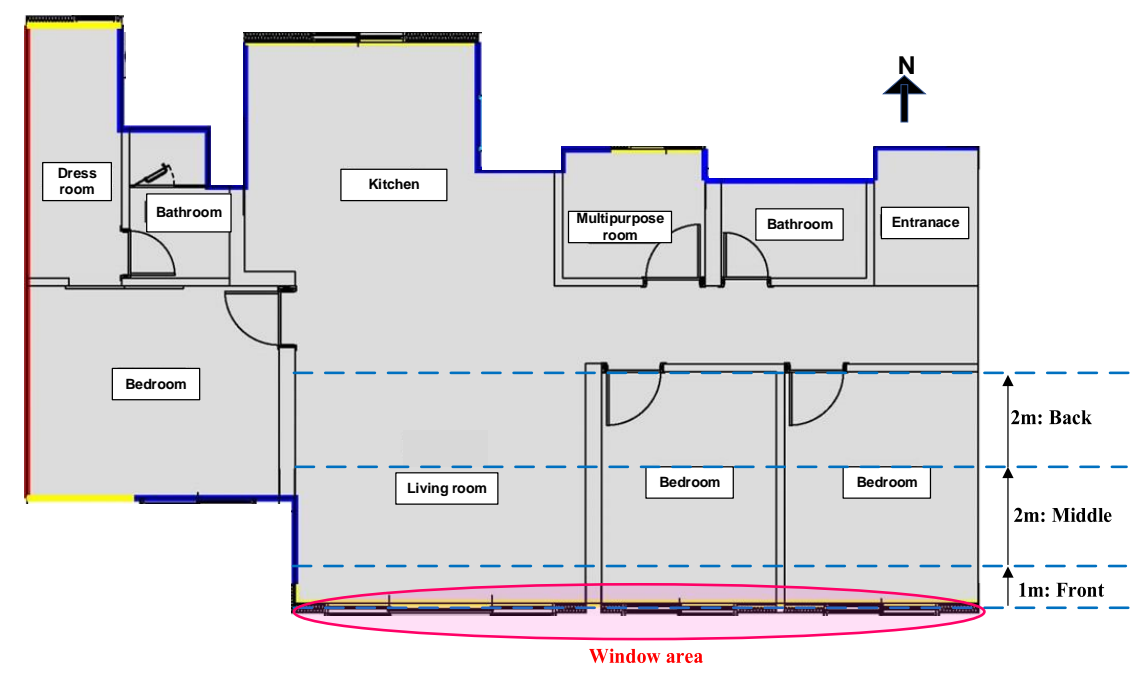

Figure 1. The plan of the selected unit of the reference residential building.

Table 1. The specification for the energy simulation.

\begin{tabular}{ll}
\hline Building System & Design Value \\
\hline Walls & $0.397 \mathrm{~W} / \mathrm{m}^{2} \mathrm{~K}$ \\
Window systems & $1.46 \mathrm{~W} / \mathrm{m}^{2} \mathrm{~K}$ \\
Shading coefficient & 0.6 \\
Air infiltration & $2.1 \mathrm{~cm}^{2} / \mathrm{m}^{2}(3.5 \mathrm{ACH} @ 50 \mathrm{PA})$ \\
& 4 occupants \\
Internal heat gain & Lighting: $5.4 \mathrm{~W} / \mathrm{m}^{2}$ \\
& Equipment: $7.0 \mathrm{~W} / \mathrm{m}^{2}$ \\
HVAC system setpoint temperature & $26^{\circ} \mathrm{C}$ for cooling and $20^{\circ} \mathrm{C}$ for heating \\
\hline
\end{tabular}

\subsection{The Selection of Shading Devices}

The main role of a shading device is to block direct sunlight as well as diffuse sunlight and reflective sunlight. Direct sunlight can be controlled simply with external shading devices, while diffuse sunlight is usually controlled with internal shading devices. For the present study, 4 different 
shading devices were selected as shown in Figure 2 the design variables of these shading devices were presented in Table 2.

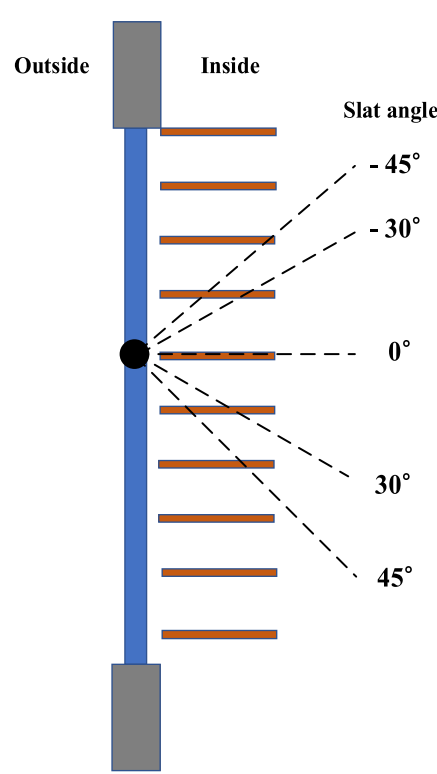

a. Venetian blind

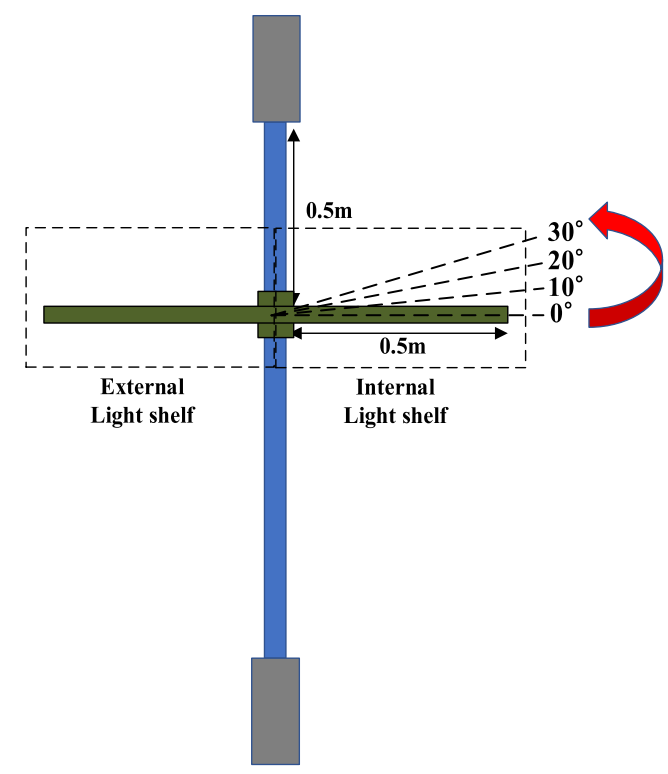

c. Light shelf

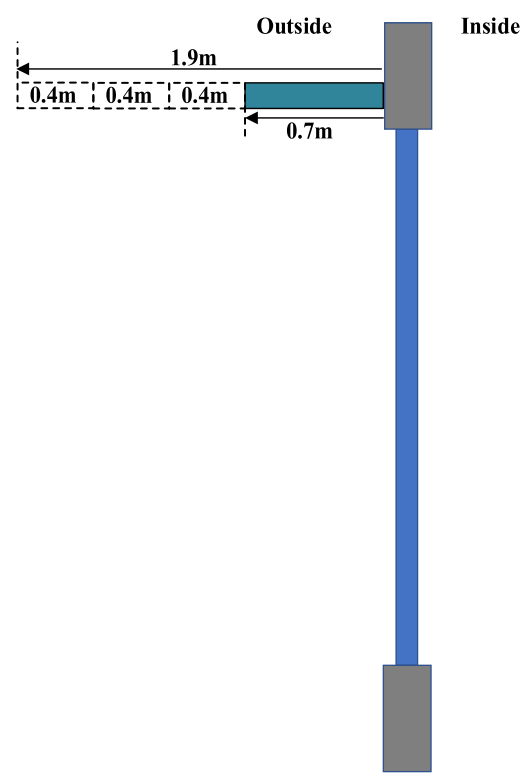

b. Overhang-shaped louver
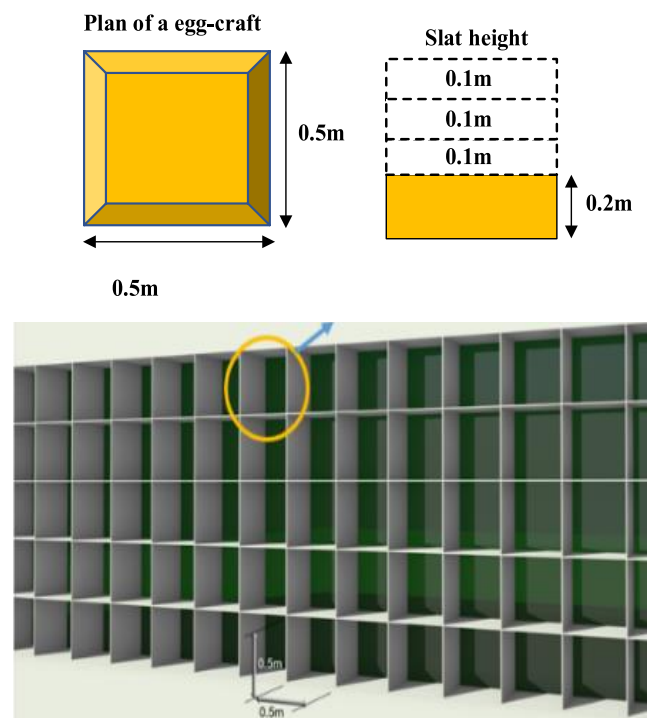

d. Egg-crate

Figure 2. Design variables of the shading devices.

Table 2. The design variables of shading devices.

\begin{tabular}{ll}
\hline Shading Device & Design Variable \\
\hline Venetian blind & Slat angles: $-45^{\circ},-30^{\circ}, 0^{\circ}, 30^{\circ}$, and $45^{\circ}$. \\
Overhang-shaped louver & Projection length: $0.7 \mathrm{~m}, 1.1 \mathrm{~m}, 1.5 \mathrm{~m}$, and $1.9 \mathrm{~m}$. \\
Light shelf & Internal shelf angles: $0^{\circ}, 10^{\circ}, 20^{\circ}$, and $30^{\circ}$. \\
Egg-crate & Vertical and horizontal slat height: $0.2 \mathrm{~m}, 0.3 \mathrm{~m}, 0.4 \mathrm{~m}$, and $0.5 \mathrm{~m}$. \\
\hline
\end{tabular}


The first shading device is the Venetian blind. The Venetian blind is generally used to control both direct and diffuse sunlight. Slat angle adjustment is the most important variable and these slats are adjusted negatively or positively when there is a need to reduce incoming light. To assess the daylighting and cooling energy performance of the Venetian blind, 5 different slat angles were set. The second shading device was an overhang-shaped horizontal louver. Since the admitted sunlight quantity can be highly influenced by the projection lengths of the louver [26], 4 different projection lengths with $0.4 \mathrm{~m}$ intervals were created for the present study. The third shading device was the light-shelf modeled based on the design guideline provided by BRE [40]. To figure out the daylighting and energy performance of an angle of the internal shelf, 4 different angles were considered. The last shading device was an egg-crate shading device that refers to a shape formed by combining the vertical and horizontal shading types. The horizontal shade functions to control direct solar radiation depending on the solar altitude, while the vertical shade functions to block or control side light depending on the change of azimuth. The plan size of each egg-crate was $0.5 \mathrm{~m}$ by $0.5 \mathrm{~m}$. For the present study, 4 different heights of a vertical and horizontal slat were considered for the assessment since the solar radiation differs by the heights of the egg-crate.

\subsection{Simulation for the Assessment of Daylighting and Cooling Energy}

To evaluate the daylighting and energy performance of a residential building with various types of shading devices, two simulation tools were used. For the analysis of daylighting through shading devices, the Radiance was used, which was developed by the lighting research team of the LBNL (Lawrence Berkeley National Laboratory) in the US [41]. By verifying and visualizing light rays from the light source, illuminance through shading devices was calculated. The simulation conditions were based on IES (Illuminating Engineering Society) guidelines as presented in Table 3 [42].

Table 3. Input parameters for the Radiance.

\begin{tabular}{ll}
\hline \multicolumn{1}{c}{ Input Parameters } & Value \\
\hline Orientation & South-facing window \\
Time & June and December 21 (noon) \\
Sky condition & CIE Clear sky for direct sunlight \\
Glazing visual Transmittance & $70 \%$ : Glazing double pane Low E \\
& $20 \%:$ A standard floor made by an opaque material \\
Material properties & $70 \%:$ A standard ceiling \\
(Reflectance) & $50 \%:$ A standard wall \\
& $50 \%:$ A standard external shadings and curtain wall frames \\
\hline
\end{tabular}

Based on the building description above and the specifications of the building envelopes (Table 1), the energy simulation was performed. In addition, hot water and space heating was assumed to be provided by the central heating systems fueled by natural gas. Compact Fluorescent lamps were mainly used as a lighting system. For the weather condition, the "Seoul" EPW (Energy Plus Weather format) file in South Korea was used. The energy model was created by using the SketchUp program (Figure 3). The design variables of shading devices were also modeled by using SketchUp for energy simulation. For the evaluation of the cooling energy, IES VE was selected as a building energy simulation program [43]. 


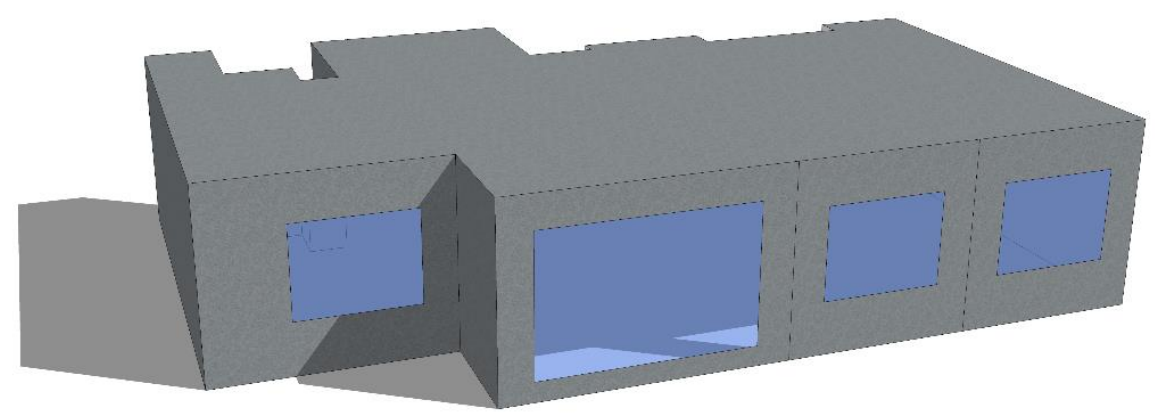

Figure 3. The energy model created by SketchUp.

Since the energy performance of shading devices in a building can be varied by the degree of indoor temperature in the space, the design temperature in the cooling season was set to $20^{\circ} \mathrm{C}$. For the energy consumption comparison, the annual energy consumption operated by each shading device was compared. By using the coefficient of variation of the root mean squared error (CV(RMSE)) provided by ASHRAE Guideline 14, the monthly energy consumption of the reference residential building without any shading devices was compared with the energy simulation [44]. The models will be declared to be calibrated if they produce $C V(R M S E)$ s within $\pm 15 \%$ with monthly energy data

$$
\begin{aligned}
& R M S E=\sqrt{\frac{\sum_{i=1}^{n}\left(M_{i}-S_{i}\right)^{2}}{n}} \\
& \mathrm{C}_{V}(R M S E)=\frac{R M S E}{M_{a v g}} \times 100
\end{aligned}
$$

where $M_{i}$ is the energy consumption of the residential building, while $S_{i}$ is the monthly energy consumption by energy simulation. $\mathrm{N}$ is the period and $M_{a v g}$ is the average for the energy consumption of the residential building.

\section{Result}

\subsection{Daylighting Performance}

Since the solar azimuth changes depending on the changes of time and seasons, to evaluate by season, the daylighting performance in the front, middle, and back areas were assessed for the standard time of noon during the spring and autumn equinoxes, the summer solstice, and the winter solstice.

\subsubsection{The Venetian Blind}

As shown in Figure 4, the illuminance was decreased when the slats of the blind were parallel to the $\mathrm{X}$-axis of the window $\left(0^{\circ}\right)$ about $90 \%$ in the front area during the summer. When the slat angles were set to $-30^{\circ}$ and $-45^{\circ}$, the illuminance was also significantly decreased in the front area, while the positive slat angles of the blind exceeded 12,000 lux during the summer. According to the lighting handbook of IESNA, the recommended light level ranges 200-300 lux for residential buildings [45]. The observed illuminance levels in the front area during the summer through the slat angles of $-30^{\circ}$ and $-45^{\circ}$ were satisfied with the recommendation of IESNA. While the illuminance with the slat angle of $0^{\circ}$ was somewhat higher than the recommendation of IESNA, this slat angle can be applied to the summer season because the illuminance level was decreased in the middle and back areas. The other two positive slat angles may cause discomfort such as glare. During the winter, the positive angles of the blind admitted more illuminance than the negative angles of the blind in the middle area of the space. Considering the obtained results, it can be seen that the illuminance level can be highly influenced by the slat angles of the blind. 


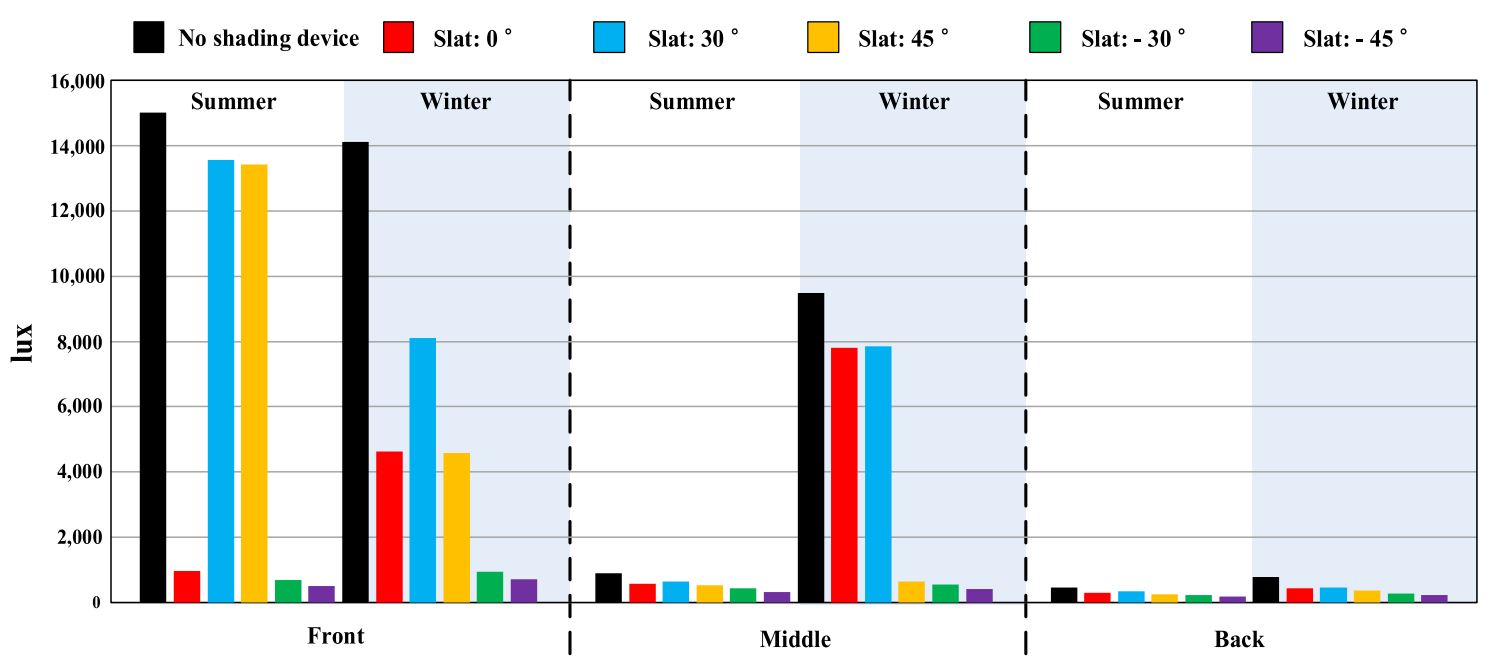

Figure 4. Daylighting performance through the Venetian blind.

\subsubsection{The Overhang-Shaped Louver}

When the projection length was ranged from $0.7 \mathrm{~m}$ to $1.1 \mathrm{~m}$, about $50 \%$ of the illuminance was reduced compared to the building without a shading device in the front area during the summer as shown in Figure 5. As the projection length was increased from $1.1 \mathrm{~m}$ to $1.9 \mathrm{~m}$, the illuminance was significantly reduced to below 1000 lux. Even though this illuminance level was somewhat higher than the IESNA recommendation, the projection length from $1.1 \mathrm{~m}$ to $1.9 \mathrm{~m}$ can be applied because the illuminance level in the middle and back areas was close to the recommendation. During the winter, there was a slight illuminance difference among the cases with various projection lengths in the front area.

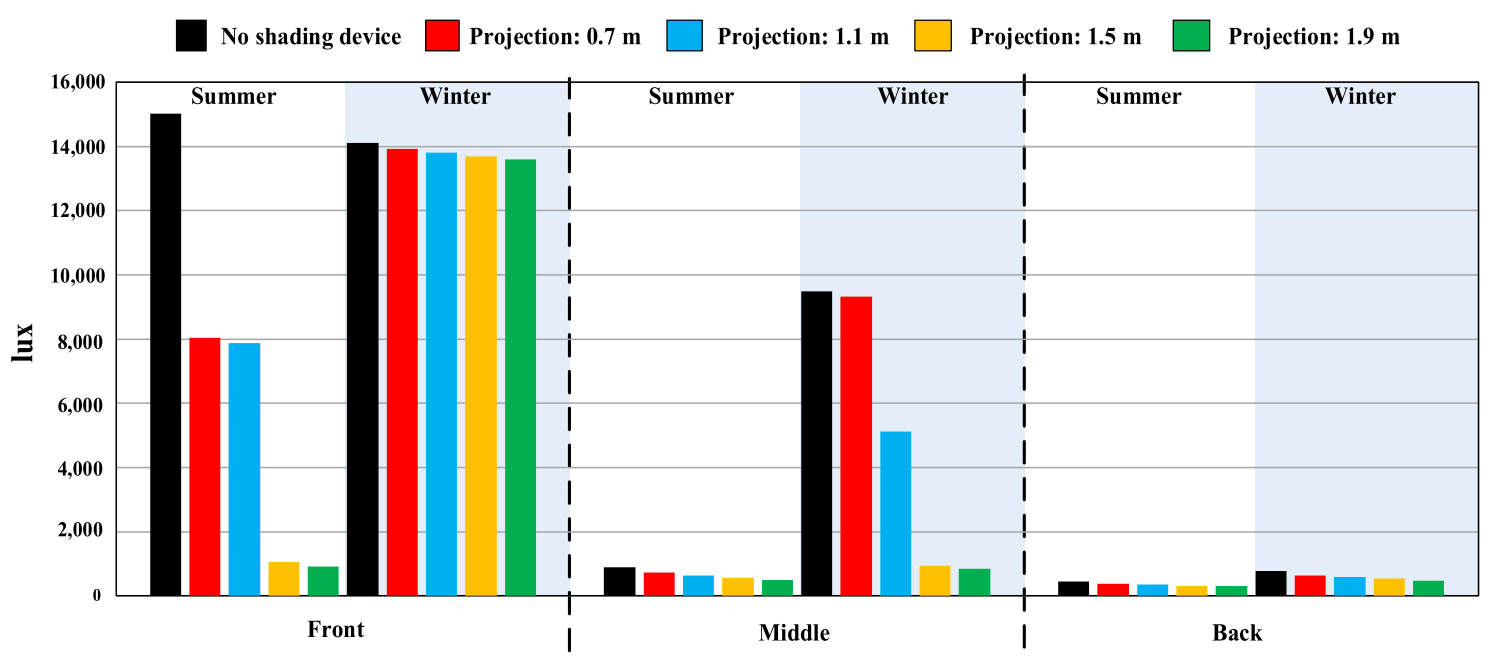

Figure 5. Daylighting performance through the overhang-shaped louver.

\subsubsection{The Light Shelf}

In the case of the light shelf, the illuminance level was measured when applying four different internal shelf angles in a building (Figure 6). Comparing the illuminance in the reference building without a shading device, the illuminance of all the cases was significantly reduced to below 1000 lux in the front area during the summer. In addition, there was a little illuminance difference among the cases with the angles of the internal shelf from $0^{\circ}$ to $30^{\circ}$. A similar trend was also observed in the front area during the winter. Thus, it can be seen that the angle of the internal shelf had little impact on the illuminance in a building. 


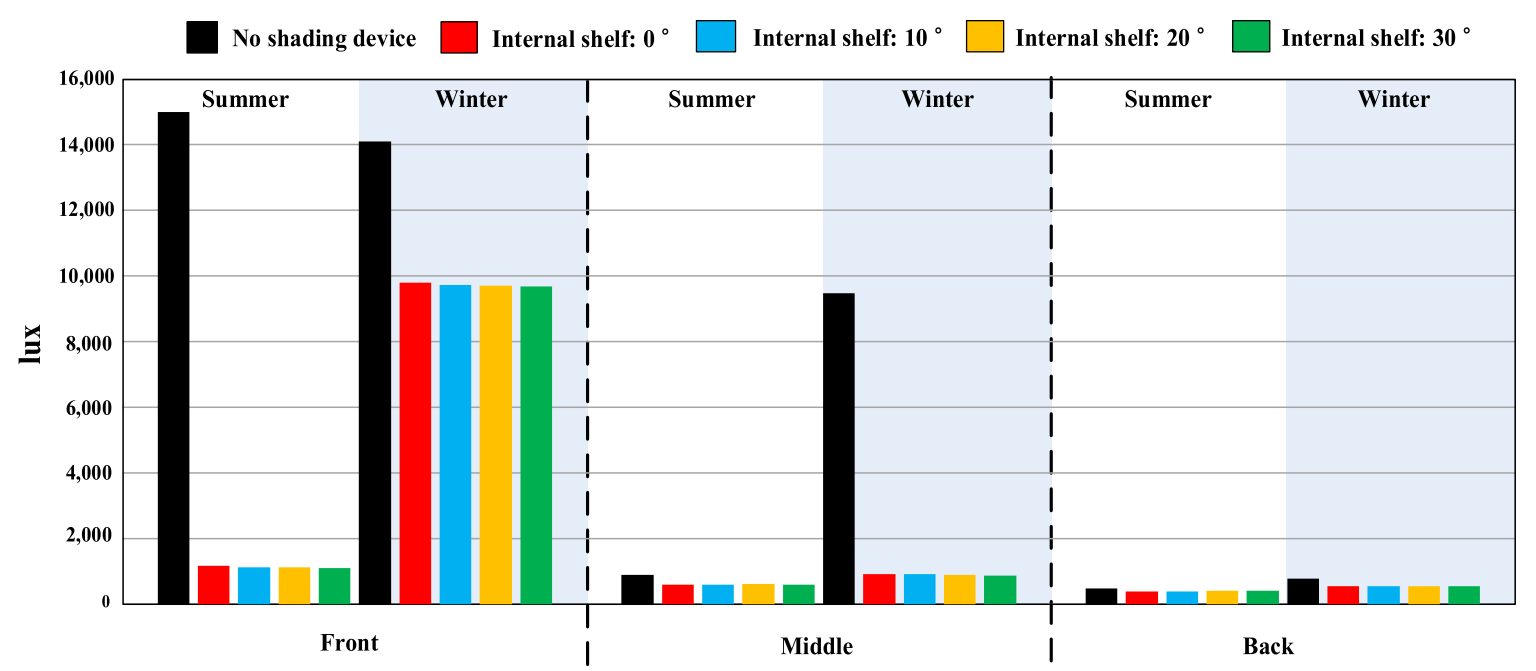

Figure 6. Daylighting performance through the light shelf.

\subsubsection{The Egg-Crate}

During the summer, the illuminance was reduced to below 2000 lux in the front area when the egg-crate shading was applied (Shown in Figure 7). While there was a little illuminance increase about $10 \%$ from with the vertical and horizontal slat height increase from $0.2 \mathrm{~m}$ to $0.3 \mathrm{~m}$, the illuminance was significantly reduced as with the increase in the vertical and horizontal slat height during the summer in the front area. During the winter, $30 \%$ of the illuminance was reduced from the building without a shading device to the cases with the vertical and horizontal slat heights of $0.2 \mathrm{~m} \sim 0.3 \mathrm{~m}$ in the front area. As the vertical and horizontal slat height was increased, about $45 \%$ of the illuminance was additionally decreased. Based on the result, the use of the egg-crate shading can effectively reduce the illuminance in a building during the summer while admitting sunlight during the winter.

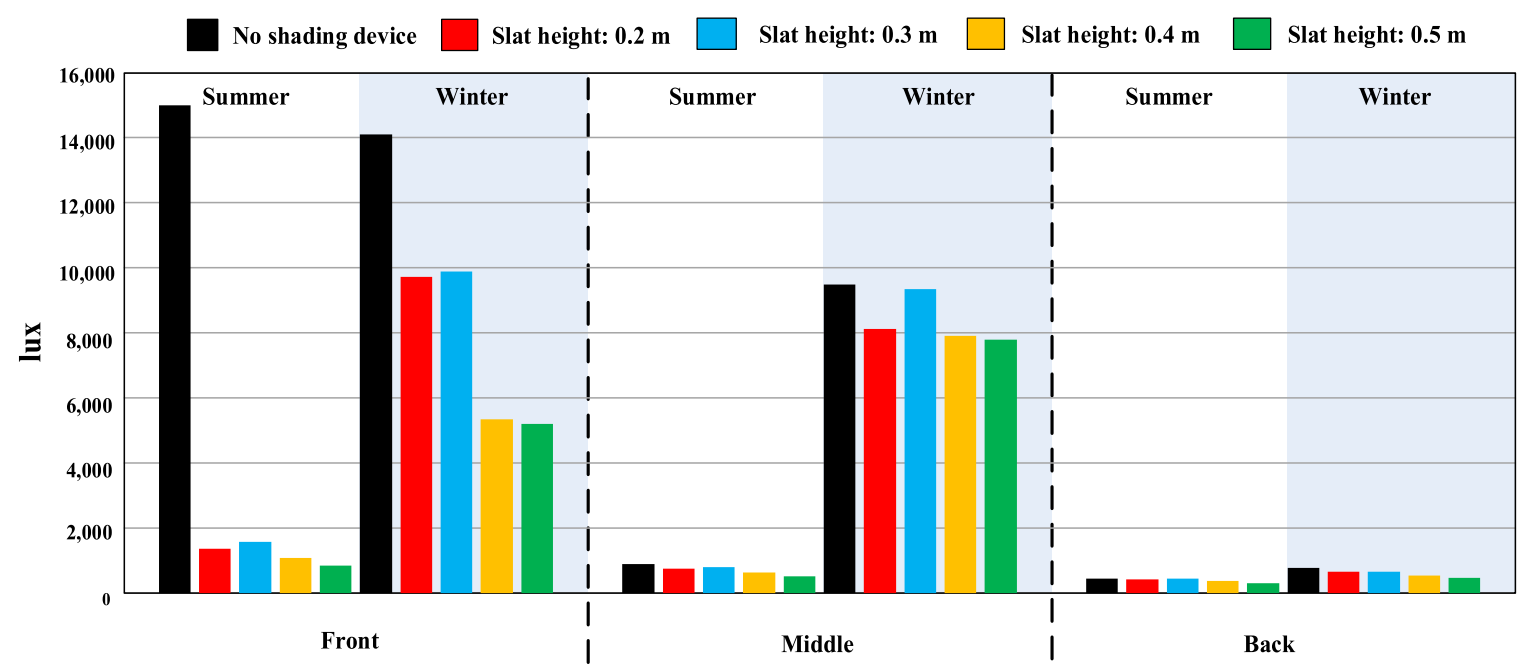

Figure 7. Daylighting performance through the egg-crate.

\subsection{The Analysis of Annual Cooling Energy Consumption by Shading Devices}

\subsubsection{The Comparison between Energy Simulation and the Monthly Energy Consumption}

To validate the energy simulation, the monthly energy consumption of the reference residential building was compared with the energy prediction by the simulation. The total energy consumption of the residential building was about 76.4 MWh, while there was a 5\% decrease for the energy use predicted by the energy simulation. As shown in Figure 8, the largest difference was observed in 
April, which about 30\%. Specifically, the root-mean-squared errors (CV(RMSEs) were calculated and these were ranged from 0.16 to 3.5 (Table 4). Since these results were within the acceptable range, the predicted results by the simulation met the requirement by ASHRAE Guideline 14 [44].

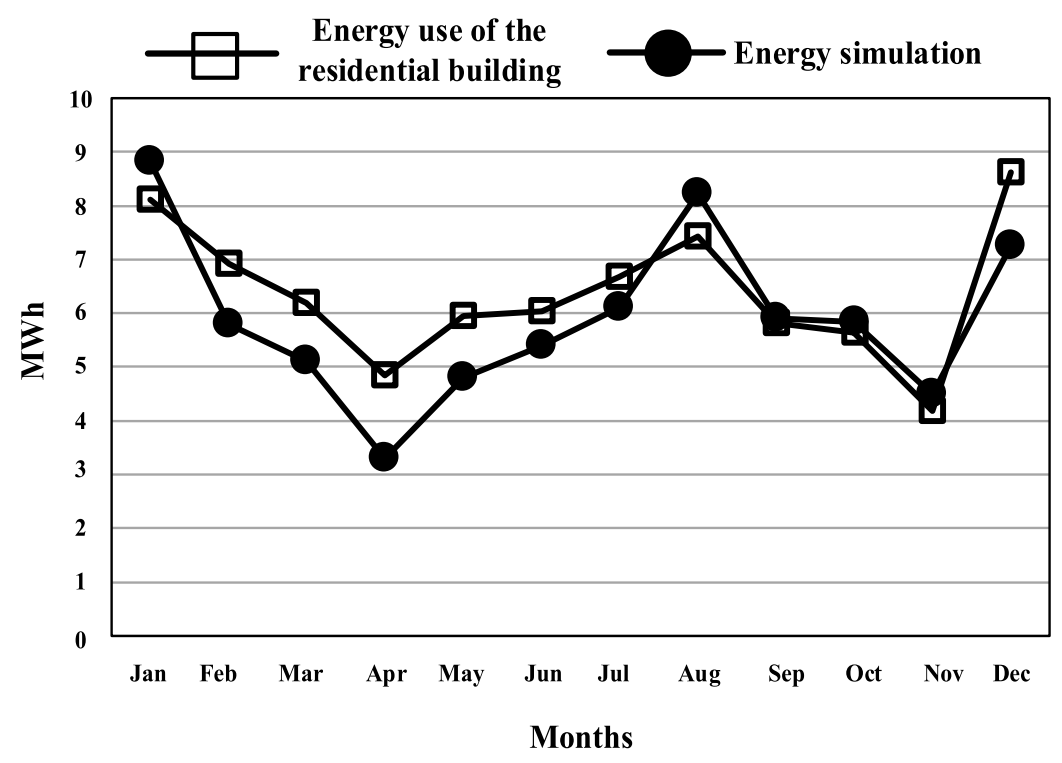

Figure 8. Energy consumption comparison between the reference residential building and the energy simulation.

Table 4. The monthly energy consumption comparison for the reference case.

\begin{tabular}{ccccc}
\hline \multirow{2}{*}{ Month } & \multicolumn{2}{c}{ Energy Consumption (MWh) } & CV(RMSE) \\
\cline { 2 - 5 } & $\begin{array}{c}\text { The Reference Residential } \\
\text { Building, 2017 }\end{array}$ & $\begin{array}{c}\text { Energy } \\
\text { Simulation }\end{array}$ & Difference & $\begin{array}{c}\text { Sima } \\
\text { January }\end{array}$ \\
\hline February & 8.1 & 8.8 & -0.7 & 2.54 \\
\hline March & 6.9 & 5.8 & 1.1 & 2.46 \\
\hline April & 6.2 & 5.1 & 1.1 & 3.50 \\
\hline May & 4.8 & 3.3 & 1.5 & 2.61 \\
\hline June & 5.9 & 4.8 & 1.1 & 1.46 \\
\hline July & 6.0 & 5.4 & 0.6 & 1.34 \\
\hline August & 6.7 & 6.1 & 0.6 & 1.85 \\
\hline September & 7.4 & 8.2 & -0.8 & 0.16 \\
\hline October & 5.8 & 5.9 & -0.1 & 0.48 \\
\hline November & 5.6 & 5.8 & -0.2 & 0.72 \\
\hline December & 4.2 & 4.5 & -0.3 & 3.10 \\
\hline
\end{tabular}

\subsubsection{The Cooling Energy Comparison by Shading Devices}

To find the most effective shading device for reducing cooling demand in a residential building, the annual cooling energy consumption by four shading devices was compared (Figure 9). When applying the Venetian blind in a building, about $14 \%$ of the annual cooling energy was reduced. Among five different slat angles, the largest cooling energy was reduced by about $18 \%$, when the slat angle was set to $45^{\circ}$. Conversely, the smallest amount of cooling energy was reduced, which was about $8 \%$, when a slat angle was set to $-45^{\circ}$. It can be seen that the reduction of cooling energy consumption was varied with the different slat angles of the blind. In the case of the overhang-shaped louver, the annual 
cooling energy was reduced as the projection length was increased. When the projection length was $1.9 \mathrm{~m}$, the largest energy consumption reduction was observed, which was about $51 \%$ of the total annual cooling energy consumption. The average cooling energy reduction was about $32 \%$ with the louver. When the projection length was $0.7 \mathrm{~m}$, only $6 \%$ of the cooling energy was reduced. As can be shown, the cooling energy in a building with the overhang-shaped louver was highly influenced by the projection lengths of the louver. Moreover, about $30 \%$ of annual cooling energy saving was made when the light shelf was used. However, there was little difference in the cooling energy consumption reduction among the cases with different angles of the internal shelf. Therefore, the angles of the internal shelf have a less impact on cooling energy consumption in a building. Lastly, about $50 \%$ of the annual cooling energy consumption was reduced with the egg-crate shading in a building. As the length of vertical and horizontal slats was increased, the cooling energy consumption reduction was also increased. The largest energy-saving was obtained, when the vertical and horizontal slats were $0.5 \mathrm{~m}$, which was about $54 \%$.

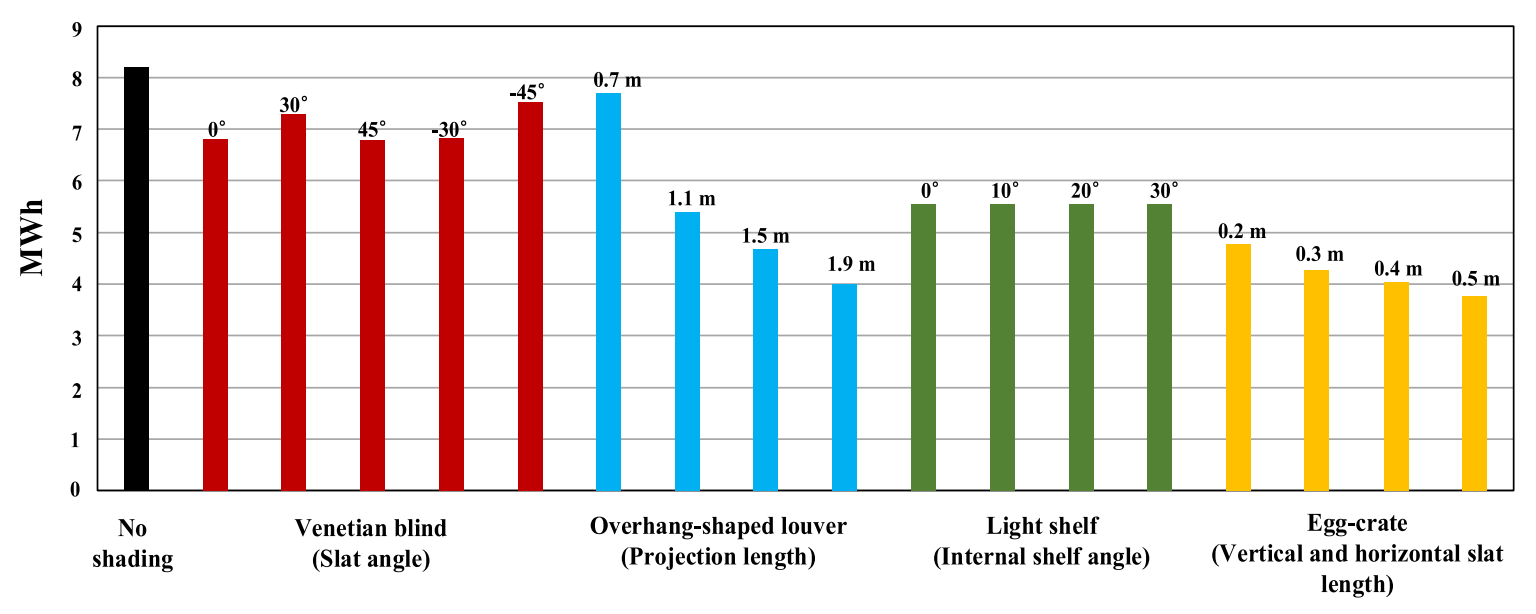

Figure 9. The reduction of annual cooling energy consumption by shading devices.

In sum, the use of an overhang-shaped louver with a projection length of $1.9 \mathrm{~m}$ and the egg-crate shading with a vertical and horizontal slat height of $0.5 \mathrm{~m}$ can effectively reduce the annual cooling energy consumption in a residential building among various shading devices.

\section{Discussion}

For the present study, the daylighting and energy performance of shading devices in a residential building was assessed. As can be shown above, each design variable had a different impact on the illuminance level and cooling energy demand in the building. Considering the daylighting performance, the light shelf, and the egg-crate effectively blocked sunlight in the front area during the summer more effectively than the others, while the overhang-shaped louver and the egg-crate shading had more impact on reducing the cooling energy consumption than the others. A similar result was obtained through the study of Alhuwayil et al. [20]. According to their result, the energy-saving was increased as the fin widths and the projection lengths of the overhang were increased. This was also mentioned in the present study. In addition, Alzoubi and Al-Zoubi [46] have investigated the energy performance of three types of external shadings including vertical, horizontal, and horizontal $45^{\circ}$. They concluded that the most effective shading for the reduction of energy consumption was the vertical shading device. This showed a similar result to the present study. Even though the egg-crate in the present study is not the vertical shading device, it showed the best overall performance among other shading devices by blocking the sun both horizontally and vertically.

In the present study, the annual energy consumption was calculated for the IES VE simulation. However, the time and date for the Radiance simulation program were set on only two days such as June and December 21st at noon to find the most effective shading devices during the summer and 
winter as well as reduce the computational resources, while other studies have considered the annual daylighting performance [20,47-49]. Considering the outcome of the present study, the obtained illuminance levels can be overestimated or underestimated. Thus, it is necessary to consider annual daylighting performance for further study.

Moreover, it can be seen that the performance difference between daylighting and cooling energy consumption was caused by the illuminance in the middle and back areas. This can influence other loads in buildings. Thus, it is necessary to evaluate other building energy use such as artificial lighting. As mentioned previously, the best shading device for reducing the cooling energy consumption was the egg-crate shading with a vertical and horizontal slat height of $0.5 \mathrm{~m}$, and the second one was the overhang-shaped louver with a projection length of $1.9 \mathrm{~m}$. However, there was only a $3 \%$ difference in annual cooling energy consumption between the two strategies. To find out the shading device with the best overall performance, the artificial lighting loads by these strategies were compared. As can be shown in Figure 10, about 15\% of energy saving for the artificial load was obtained by using the egg-crate shading with a vertical and horizontal slat height of $0.5 \mathrm{~m}$, while $5 \%$ of artificial lighting energy was reduced by the overhang-shaped louver. Therefore, the use of the eff-crate was a more effective shading device for blocking sunlight as well as reducing cooling energy demand in a residential building than the overhang-shaped louver.

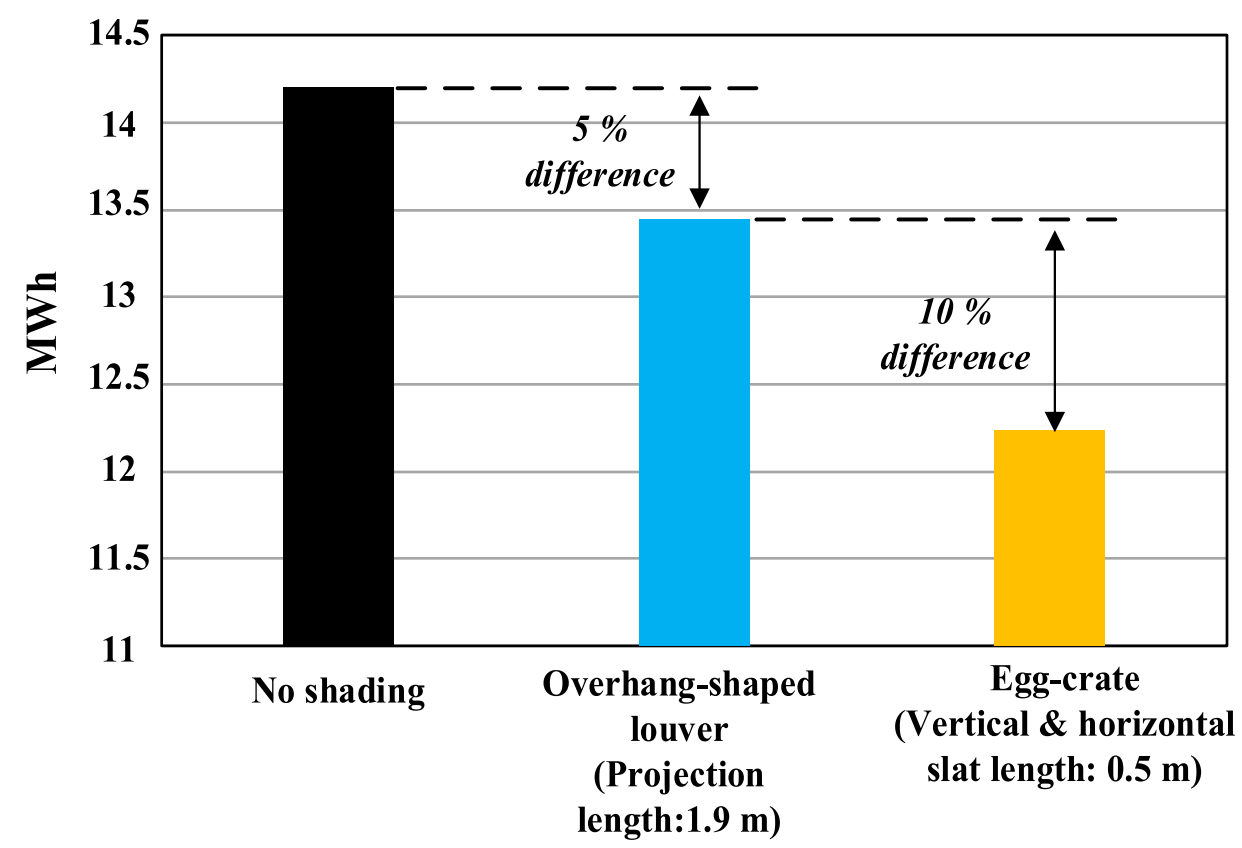

Figure 10. The reduction of artificial lighting energy consumption by two shading devices.

\section{Conclusions}

As one of the main contributors to energy consumption in South Korea, the number of residential building has gradually increased and the energy consumed by residential buildings has become the main concern. Thus, many studies have been conducted to reduce energy consumption in residential buildings by applying passive and active design solutions. In addition, several renewable energy systems were used to improve energy efficiency in residential buildings. In South Korea, the energy demand for cooling in residential buildings has been increasing rapidly. Focusing on possible passive design strategies, the present study investigated the daylight and cooling performance of several shading devices in a residential building.

Among various types of shading devices, four shading devices were selected including the Venetian blind, horizontal louver, light shelf, and egg-crate. Using two different simulations, the illuminance level and annual cooling energy reduction by various design variables of these shading devices were 
analyzed. For both assessments, the illuminance and cooling energy performance were varied by the design options of shading devices. For the daylight assessment, all the shading devices blocked the sunlight effectively. Specifically, the light shelf and egg-crate were able to block a significant amount of sunlight in a building during the summer, while admitting sunlight during the winter. Regarding the cooling energy consumption, the overhang-shaped louver and egg-crate were able to reduce the cooling demand more effectively than the other shading devices. Among various design options of these two devices, the overhang-shaped louver with a projection length of $1.9 \mathrm{~m}$ and the egg-crate shading with a vertical and horizontal slat height of $0.5 \mathrm{~m}$ reduced about $51 \%$ to $54 \%$ of the annual cooling energy consumption. Because of only a 3\% difference in the cooling energy consumption, the artificial lighting loads of these two design options were compared. As a result, about $15 \%$ of the artificial lighting load was reduced by the use of the egg-crate shading with a vertical and horizontal slat height of $0.5 \mathrm{~m}$, while the overhang-shaped louver only reduced $5 \%$ of the load. Therefore, it is necessary to consider both daylight and energy performance for developing energy reduction strategies by using shading devices.

Considering the outcome of the present study, the proper use of shading devices has the potential for energy saving by reducing the cooling and artificial lighting loads in a building. Moreover, the obtained result can be used for the development of energy-efficient building design. Finally, it can reduce greenhouse gas emissions. For further study, more various design options and shading devices will be included in the analysis of energy efficiency and daylighting performance. In addition, it is necessary to consider the annual daylighting performance for more accurate analysis.

Author Contributions: T.L. and W.S.Y. designed and performed the simulation and collected the data. D.D.K. wrote the manuscript and analyzed the data. All authors have read and agreed to the published version of the manuscript.

Funding: This research received no external funding

Conflicts of Interest: The authors declare no conflict of interest.

\section{References}

1. Kim, M.J.; Cho, M.E.; Kim, J.T. Energy use of households in apartment complexes with different service life. Energy Build. 2013, 66, 591-598. [CrossRef]

2. Ihm, P.; Park, L.; Krarti, M.; Seo, D. Impact of window selection on the energy performance of residential buildings in south korea. Energy Policy 2012, 44, 1-9. [CrossRef]

3. The Annual Energy Consumption in 2017. Korea Energy Agency. Available online: http://www.Energy.Or. Kr/renew_eng/main/main.Aspx (accessed on 10 January 2019).

4. Choi, I.Y.; Cho, S.H.; Kim, J.T. Energy consumption characteristics of high-rise apartment buildings according to building shape and mixed-use development. Energy Build. 2012, 46, 123-131. [CrossRef]

5. Seo, Y.-K.; Hong, W.-H. Constructing electricity load profile and formulating load pattern for urban apartment in korea. Energy Build. 2014, 78, 222-230. [CrossRef]

6. Lee, S.; Kim, S.; Na, Y. Comparative analysis of energy related performance and construction cost of the external walls in high-rise residential buildings. Energy Build. 2015, 99, 67-74. [CrossRef]

7. Park, J.S.; Lee, S.J.; Kim, K.H.; Kwon, K.W.; Jeong, J.-W. Estimating thermal performance and energy saving potential of residential buildings using utility bills. Energy Build. 2016, 110, 23-30. [CrossRef]

8. Sharma, V.; Rai, A.C. Performance assessment of residential building envelopes enhanced with phase change materials. Energy Build. 2020, 208, 109664. [CrossRef]

9. Yaşar, Y.; Kalfa, S.M. The effects of window alternatives on energy efficiency and building economy in high-rise residential buildings in moderate to humid climates. Energy Convers. Manag. 2012, 64, 170-181. [CrossRef]

10. Tetlow, D.; De Simon, L.; Liew, S.Y.; Hewakandamby, B.; Mack, D.; Thielemans, W.; Riffat, S. Cellulosic-crystals as a fumed-silica substitute in vacuum insulated panel technology used in building construction and retrofit applications. Energy Build. 2017, 156, 187-196. [CrossRef] 
11. Park, J.H.; Wi, S.; Chang, S.J.; Kim, S. Analysis of energy retrofit system using latent heat storage materials applied to residential buildings considering climate impacts. Appl. Therm. Eng. 2020, 169, 114904. [CrossRef]

12. De Gracia, A. Dynamic building envelope with pcm for cooling purposes-proof of concept. Appl. Energy 2019, 235, 1245-1253. [CrossRef]

13. Sghiouri, H.; Mezrhab, A.; Karkri, M.; Naji, H. Shading devices optimization to enhance thermal comfort and energy performance of a residential building in morocco. J. Build. Eng. 2018, 18, 292-302. [CrossRef]

14. Fine, J.P.; Gray, J.; Tian, X.; Touchie, M.F. An investigation of alternative methods for determining envelope airtightness from suite-based testing in multi-unit residential buildings. Energy Build. 2020, 214, 109845. [CrossRef]

15. Gasparella, A.; Pernigotto, G.; Cappelletti, F.; Romagnoni, P.; Baggio, P. Analysis and modelling of window and glazing systems energy performance for a well insulated residential building. Energy Build. 2011, 43, 1030-1037. [CrossRef]

16. Berardi, U.; Kisilewicz, T.; Kim, S.; Lechowska, A.; Paulos, J.; Schnotale, J. Experimental and numerical investigation of the thermal transmittance of pvc window frames with silica aerogel. J. Build. Eng. 2020, 2020, 101665. [CrossRef]

17. Paulos, J.; Berardi, U. Optimizing the thermal performance of window frames through aerogel-enhancements. Appl. Energy 2020, 266, 114776. [CrossRef]

18. Cho, J.; Yoo, C.; Kim, Y. Viability of exterior shading devices for high-rise residential buildings: Case study for cooling energy saving and economic feasibility analysis. Energy Build. 2014, 82, 771-785. [CrossRef]

19. Liu, S.; Kwok, Y.T.; Lau, K.K.-L.; Chan, P.W.; Ng, E. Investigating the energy saving potential of applying shading panels on opaque façades: A case study for residential buildings in hong kong. Energy Build. 2019, 193, 78-91. [CrossRef]

20. Alhuwayil, W.K.; Abdul Mujeebu, M.; Algarny, A.M.M. Impact of external shading strategy on energy performance of multi-story hotel building in hot-humid climate. Energy 2019, 169, 1166-1174. [CrossRef]

21. Huo, H.; Xu, W.; Li, A.; Cui, G.; Wu, Y.; Liu, C. Field comparison test study of external shading effect on thermal-optical performance of ultralow-energy buildings in cold regions of china. Build. Environ. 2020, 180, 106926. [CrossRef]

22. Chan, A.L.S. Effect of adjacent shading on the energy and environmental performance of photovoltaic glazing system in building application. Energy 2019, 187, 115939. [CrossRef]

23. Mun, S.-H.; Kwak, Y.; Huh, J.-H. A case-centered behavior analysis and operation prediction of ac use in residential buildings. Energy Build. 2019, 188-189, 137-148. [CrossRef]

24. Song, D.; Choi, Y.-J. Effect of building regulation on energy consumption in residential buildings in korea. Renew. Sustain. Energy Rev. 2012, 16, 1074-1081. [CrossRef]

25. Kristl, Ž.; Košir, M.; Trobec Lah, M.; Krainer, A. Fuzzy control system for thermal and visual comfort in building. Renew. Energy 2008, 33, 694-702. [CrossRef]

26. Palmero-Marrero, A.I.; Oliveira, A.C. Effect of louver shading devices on building energy requirements. Appl. Energy 2010, 87, 2040-2049. [CrossRef]

27. Lim, Y.-W.; Kandar, M.Z.; Ahmad, M.H.; Ossen, D.R.; Abdullah, A.M. Building façade design for daylighting quality in typical government office building. Build. Environ. 2012, 57, 194-204. [CrossRef]

28. Bellia, L.; De Falco, F.; Minichiello, F. Effects of solar shading devices on energy requirements of standalone office buildings for italian climates. Appl. Therm. Eng. 2013, 54, 190-201. [CrossRef]

29. Al-Tamimi, N.A.; Fadzil, S.F.S. The potential of shading devices for temperature reduction in high-rise residential buildings in the tropics. Procedia Eng. 2011, 21, 273-282. [CrossRef]

30. Gratia, E.; De Herde, A. The most efficient position of shading devices in a double-skin facade. Energy Build. 2007, 39, 364-373. [CrossRef]

31. Uribe, D.; Vera, S.; Bustamante, W.; McNeil, A.; Flamant, G. Impact of different control strategies of perforated curved louvers on the visual comfort and energy consumption of office buildings in different climates. Sol. Energy 2019, 190, 495-510. [CrossRef]

32. Bessoudo, M.; Tzempelikos, A.; Athienitis, A.K.; Zmeureanu, R. Indoor thermal environmental conditions near glazed facades with shading devices - part i: Experiments and building thermal model. Build. Environ. 2010, 45, 2506-2516. [CrossRef]

33. Datta, G. Effect of fixed horizontal louver shading devices on thermal perfomance of building by trnsys simulation. Renew. Energy 2001, 23, 497-507. [CrossRef] 
34. Tzempelikos, A.; Athienitis, A.K. The impact of shading design and control on building cooling and lighting demand. Sol. Energy 2007, 81, 369-382. [CrossRef]

35. Cheng, C.-L.; Liao, L.-M.; Chou, C.-P. A study of summarized correlation with shading performance for horizontal shading devices in taiwan. Sol. Energy 2013, 90, 1-16. [CrossRef]

36. Koo, S.Y.; Yeo, M.S.; Kim, K.W. Automated blind control to maximize the benefits of daylight in buildings. Build. Environ. 2010, 45, 1508-1520. [CrossRef]

37. Frontini, F.; Kuhn, T.E. The influence of various internal blinds on thermal comfort: A new method for calculating the mean radiant temperature in office spaces. Energy Build. 2012, 54, 527-533. [CrossRef]

38. Korea Meteorological Administration. Available online: https://www.Weather.Go.Kr/weather/main.Jsp (accessed on 10 January 2019).

39. Korean Statistical Information Service. Available online: http://kosis.Kr/index/index.Do (accessed on 10 January 2019).

40. Rennie, D.; Parand, F. Environmental Design Guide for Naturally Ventilated and Daylit Offices; Building Research Communications Ltd.: London, UK, 1998.

41. Radiane. Available online: https://windows.Lbl.Gov/software/radiance (accessed on 24 May 2019).

42. Illuminating Engineering Society of North America (IESNA). Ies Spatial Daylight Autonomy (SDA) and Annual Sunlight Exposure (ASE); lm-83-12; Iesna Lighting Measurement: New York, NY, USA, 2012.

43. IES VE. Available online: https://www.Iesve.Com/software/virtual-environment (accessed on 24 May 2019).

44. American Society of Heating, Refrigerating and Air Conditioning Engineers. Ashrae Guideline 14-2002, Measurement of Energy and Demand Savings-Measurement of Energy, Demand and Water Savings; American Society of Heating, Refrigerating and Air Conditioning Engineers: Atlanta, GA, USA, 2002.

45. David, L.D.; Houser, K.; Mistrick, R.; Steffy, G.R. The Lighting Handbook, 10th ed.; Illuminating Engineering Society: New York, NY, USA, 2011. Available online: https://www.Ies.Org/ (accessed on 24 May 2019).

46. Alzoubi, H.H.; Al-Zoubi, A.H. Assessment of building façade performance in terms of daylighting and the associated energy consumption in architectural spaces: Vertical and horizontal shading devices for southern exposure facades. Energy Convers. Manag. 2010, 51, 1592-1599. [CrossRef]

47. Nematchoua, M.K.; Noelson, J.C.V.; Saadi, I.; Kenfack, H.; Andrianaharinjaka, A.-Z.F.R.; Ngoumdoum, D.F.; Sela, J.B.; Reiter, S. Application of phase change materials, thermal insulation, and external shading for thermal comfort improvement and cooling energy demand reduction in an office building under different coastal tropical climates. Sol. Energy 2020, 207, 458-470. [CrossRef]

48. Han, Y.; Taylor, J.E.; Pisello, A.L. Exploring mutual shading and mutual reflection inter-building effects on building energy performance. Appl. Energy 2017, 185, 1556-1564. [CrossRef]

49. Li, D.H.W.; Wong, S.L. Daylighting and energy implications due to shading effects from nearby buildings. Appl. Energy 2007, 84, 1199-1209. [CrossRef] 